\title{
Allocation of Mobile Chippers for a Concentrated Bioenergy Demand
}

\author{
Mika Yoshida \\ Institute of Wood Technology, Akita Prefectural University, Akita, Japan \\ Email: mika@iwt.akita-pu.ac.jp
}

How to cite this paper: Yoshida, M. (2019). Allocation of Mobile Chippers for a Concentrated Bioenergy Demand. Open Journal of Forestry, 9, 283-295.

https://doi.org/10.4236/ojf.2019.94016

Received: July 17, 2019

Accepted: September 13, 2019

Published: September 16, 2019

Copyright $\odot 2019$ by author(s) and Scientific Research Publishing Inc. This work is licensed under the Creative Commons Attribution International License (CC BY 4.0).

http://creativecommons.org/licenses/by/4.0/

(c) (i) Open Access

\begin{abstract}
Allocation of mobile chippers is a tactical problem of management in a bioenergy supply chain. It influences the entire supply cost of the wood chip since the transportation distance and the chipping productivity decide the transportation cost. Great and concentrated demands of woody biomass require multiple suppliers, and there should be the best allocation of mobile chippers which minimize the entire supply cost. This study aims to clarify better management of the supply chain consisting of multiple players for a great and concentrated demand for wood chip. The model was a supply chain for a typical biomass power plant with 5.8 MW capacity. Suppliers were assumed to select mobile chippers from two sizes, $140-\mathrm{kW}$ and $353-\mathrm{kW}$. By the model simulation, it was clarified that the well-considered allocation of two different mobile chippers could reduce the entire supply cost less than the conventional system using a fixed chipper at the power plant. The best management was to use only the $353-\mathrm{kW}$ chippers, and secondly to allocate the less productive chippers closer to the demand to prevent the incline of the transportation cost. However, the possible conflict was also specified as the increased cost of the suppliers using more productive chippers in the second best allocation strategy. This result emphasizes the necessity of resolving such conflict by making the collaborative relationship among stakeholders which has been pointed out by other researches as well to sustain the better condition of the supply chain.
\end{abstract}

\section{Keywords}

Chipper Allocation, Chip Transportation, Stakeholder's Benefit, Stakeholder Collaboration, Supply Chain Management

\section{Introduction}

Sustainable forest management makes a way for the mitigation of climate change 
(Intergovernmental Panel on Climate Change, 2014) and it can be achieved by sustainable forest operation (Marchi et al., 2018). In planted forest which occupies two-fifth of Japanese forest area, the use of logging residue as bioenergy will contribute not only to create new value from the byproduct of harvesting but also to save the cost of site preparation (Yoshida, Fujiwara, \& Sakai, 2015).

Transportation is one of the most expensive operations in the supply chain of bioenergy (Ghaffariyan et al., 2017). Mobile chippers have been introduced to produce wood chip from logging residue at material landings or the roadside (Wolfsmayr \& Rauch, 2014) as a common practice realizing a lower supply cost (Ghaffariyan, Sessions, \& Brown, 2013). Collection systems using mobile chippers is, therefore, being established as a major improvement from the supplier side to improve transportation efficiency of logging residue.

For the demand side, it is reasonable to use logging residue locally for heat generation/combined heat and electric power generation since heat conversion is more efficient than generating only electric power. Woody biomass is, however, mainly used only for electric power generation in Japan, which has been accelerated by Feed-In Tariff law in 2012. Those biomass power plants need a large volume of wood chip (Kuboyama, Komata, \& Yanagida, 2017). While those power plants can reduce the capital cost by increasing their generation capacity, it increases the transportation cost in the fuel procurement process (Kumar, Cameron, \& Flynn, 2003). The fuel supply chain will also have several different companies or business units to satisfy demand. It is essential for the reduction of supply cost to manage the internal and external network by supply chain management (Simchi-Levi, Kaminsky, \& Simchi-Levi, 2008).

Since the chipping productivity and transportation distance influenced on the transportation cost (Laitila, Asikainen, \& Ranta, 2016), this study focused on the allocation of mobile chippers operated by different suppliers to material landings as a problem in a tactical level which had a direct influence on actual operations (D’Amours, Rönnqvist, \& Weintraub, 2009).

This study aims to clarify a rational management of the supply chain including multiple suppliers for a concentrated demand for the wood chip by simulating the four typical allocation strategies on a regional scale.

\section{Materials and Method}

\subsection{Spatial Condition of the Simulation}

This study set Iwate Prefecture as the model area located in North East Japan Iwate Prefecture $\left(38^{\circ} 44^{\prime} 52^{\prime \prime}\right.$ and $40^{\circ} 27^{\prime} 02^{\prime \prime}$ in longitude, $142^{\circ} 04^{\prime \prime}$ and $142^{\circ} 04^{\prime} 21^{\prime \prime}$ in latitude, Figure 1). Forest area coverage was $77 \%$ of the prefecture area, which equivalent to 1.2 Mill. ha in 2017. Its stock volume was 250 Mill. solid m $\mathrm{m}^{3}$ in 2017 according to Japanese Forestry Agency. The annual average temperature is around 10 degrees and it has snow in winter.

Unlike to other prefectures, an association for wood material distribution manages the regional supply chain of wood chip for bioenergy by meeting supply 


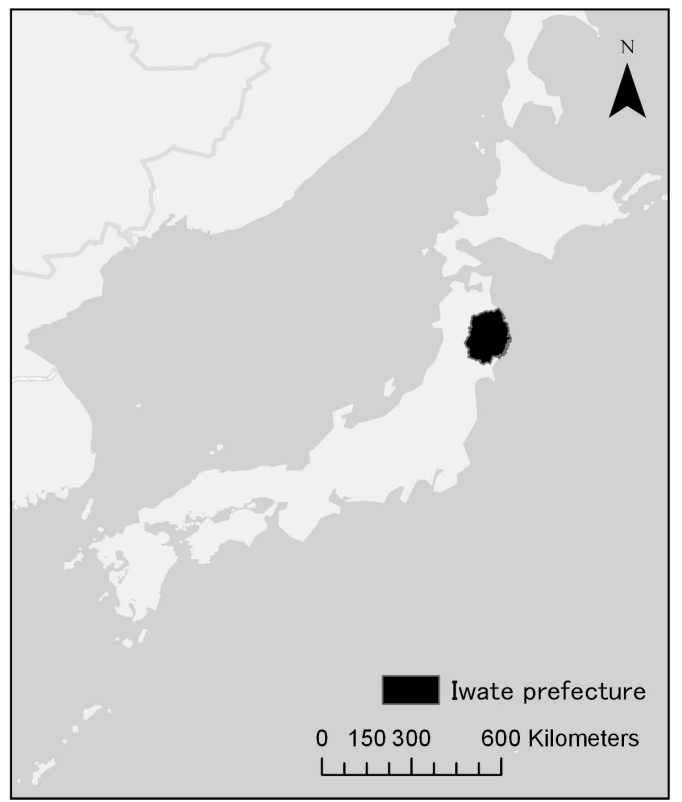

Figure 1. Location of Iwate prefecture.

and demand, by scheduling wood transportation, by negotiating the prices, and by managing the billing. The demand in this model area was a power plant with a $5.8 \mathrm{MW}$ capacity located in the center of this prefecture $\left(39^{\circ} 35^{\prime} 06.3^{\prime \prime} \mathrm{N}\right.$, $\left.141^{\circ} 39^{\prime} 48.0^{\prime \prime} \mathrm{E}\right)$. The capacity of this power plant can be regarded as a general size in Japan.

The size of annual demand $D$ was 378,000 loose $\mathrm{m}^{3}$ of wood chip which was equivalent to 135,000 solid $\mathrm{m}^{3}$ of round wood. Among the logging companies in Japan, only $12 \%$ of them produced more than 10,000 solid $\mathrm{m}^{3}$ annually (Japanese Forestry Agency, 2018). The demand for bioenergy was enormous compared to the business scale of existing logging companies in Japan. It is indispensable to involve small scale logging companies in the wood chip supply chain.

\subsection{Production System}

Wood chip production by mobile chippers was called as the promoted system in this study. In this system, both low-quality timbers and branches could be used as chip material. Two different sized mobile chippers were selected, provisionally called as middle and small chippers, as representatives according to the previous studies that classified mobile chippers by the engine power (Yoshida, Berg, Sakurai, \& Sakai, 2016; Yoshida \& Sakai, 2017). A small chipper has the engine below $200 \mathrm{~kW}$ and a middle chipper has the engine between $200 \mathrm{~kW}$ and $400 \mathrm{~kW}$.

As the representative of middle chippers, MUS-MAX WT8-XL manufactured by MUS-MAX Landmaschinenbau Urch KG in Austria was assumed. It had a $355-\mathrm{kW}$ engine and a grapple loader mounted on a truck base. It was recommended to introduce if the supplier could have a business scale for depreciation (Yoshida \& Sakai, 2017).

Suppliers with small business scale could not afford the middle chipper. Most 
of the companies were involved in this category in Japan (Japanese Forestry Agency, 2018) so that the involvement of small suppliers was vital to establish a regional supply chain as mentioned. Small mobile chippers would allow them to join in the new business (Yoshida \& Sakai, 2014). As the representative of the small chipper, Farmi 380 manufactured by Farmi Forest Oy in Finland with the $140-\mathrm{kW}$ engine was selected because it also had a grapple loader and self-mobility (Yoshida \& Sakai, 2017). The price and productivity were less than half of those of MUS-MAX. The description of supposed mobile chippers is summarized in Table 1.

On the other hand, the conventional system produced wood chip by stational chippers only from low-quality round wood that delivered to the chipping factory adjacent to the power plant.

\subsection{Production Cost}

The chipping cost $C_{\text {chip }}$ of MUS-MAX and Farmi 380 were $317 \mathrm{JPY} /$ loose $^{3}$ and $603 \mathrm{JPY} /$ loose $\mathrm{m}^{3}$, respectively, when the rate of machine utilization was 0.75 (Yoshida \& Sakai, 2017) (Table 1). The chipping cost at the chipping factory $\left(\mathrm{JPY} /\right.$ loose $\mathrm{m}^{3}$ ) calculated by the following Equation (1).

$$
C_{\text {chip }}=(X+Y+Z) / p_{\text {chip }}
$$

where $X$ was the hourly depreciation cost of factory properties (JPY/hr); $Y$, the hourly depreciation cost of machines at the factory (JPY/hr); $Z$, the variable cost

Table 1. Descriptions of mobile chippers.

\begin{tabular}{|c|c|c|}
\hline Chipper name & Farmi 380 & MUS-MAX WT8-XL \\
\hline Defined size class & Small & Middle \\
\hline Manufacturer & Farmi Forest Oy & $\begin{array}{c}\text { Mus-Max } \\
\text { Landmaschinenbau Urch KG }\end{array}$ \\
\hline Manufacturing country & Finland & Austria \\
\hline Chipping type & Disc (4 knives) & Drum (8 knives) \\
\hline Engine power $(\mathrm{kW})$ & 140 & 353 \\
\hline Initial investment (Mill. JPY) & 29 & 55 \\
\hline Depreciation years (years) & 5 & 5 \\
\hline Salvage rate & 0 & 0 \\
\hline $\begin{array}{l}\text { Rate of maintenance } \\
\text { cost to initial investment }\end{array}$ & 0.68 & 0.68 \\
\hline Interest, insurance and tax & 0.23 & 0.23 \\
\hline Productivity (loose $\mathrm{m}^{3} / \mathrm{hr}$ ) & 23.7 & 66.3 \\
\hline Fuel consumption (L/hr) & 20.6 & 13.5 \\
\hline Chipping cost (JPY/loose $\left.\mathrm{m}^{3}\right)$ & 603 & 317 \\
\hline
\end{tabular}

A small chipper has the engine below $200 \mathrm{~kW}$ and a middle chipper has the engine between $200 \mathrm{~kW}$ and $400 \mathrm{~kW}$. This classification is provisional (Yoshida \& Sakai, 2017). The chipping cost was calculated when the rate of machine utilization was 0.75 , whose method was explained in detail in the previous study (Yoshida \& Sakai, 2017). 
to run the factory (JPY/hr); and $p_{\text {chip }}$ was the productivity of a fixed chipper (loose $\mathrm{m}^{3} / \mathrm{hr}$ ) which was assumed 40 loose $\mathrm{m}^{3} / \mathrm{hr}$. The data was obtained by hearing investigation to a chipping factory in 2014, which could process about 20,000 solid $\mathrm{m}^{3} / \mathrm{yr}$ by one shift. The cost data of chipping factory was shown in Table 2, and the cost data of machines for chipping at the factory was shown in Table 3.

The transportation cost $C_{i j}$ by the supplier $i$ from the material landing $j$ was calculated on the road network in the context of minimizing the transportation time by the geographical information system (GIS) software, Esri ArcMap 10.2.2. The cost calculation method was the same as the previous study taking the interaction between chipping and transportation operations into account (Yoshida \& Sakai, 2017). The trucks were directly loaded wood chip from mobile chipper to omit the operation reloading wood chip, and drove between the material landings and the power plant. It was called a shuttle system.

Table 2. Cost data for chipping at the factory in the conventional system.

\begin{tabular}{|c|c|c|c|c|}
\hline Symbol & Sub-symbol & Definition & Unit & Formula or data \\
\hline \multirow[t]{10}{*}{$X$} & & Hourly depreciation cost of the factory properties & $\mathrm{JPY} / \mathrm{hr}$ & $F D /(D P \cdot h)$ \\
\hline & $F D$ & Investment of the factory & JPY & $F P+F C+F T$ \\
\hline & $D P$ & Depreciation years of the factory & year & 20 \\
\hline & $h$ & The productive working hours of the factory & $\mathrm{h} /$ year & 1500 \\
\hline & $F P$ & Property cost of the factory & JPY & $23,945,900$ \\
\hline & $F C$ & Construction cost of the factory & JPY & $204,519,000$ \\
\hline & $F T$ & Fixed property tax of the factory & JPY & $\sum_{i=1}^{D P} f t_{i}$ \\
\hline & $f t_{i}$ & Fixed property tax of the factory in year $i$ & JPY/year & $f t_{i-1}(1-1 / D P)$ \\
\hline & $f t_{1}$ & Fixed property tax of the factory in the first year & JPY/year & $r F P(1-1 / D P)$ \\
\hline & $r$ & Property tax ratio ${ }^{2)}$ & & 0.014 \\
\hline \multirow[t]{8}{*}{$Y^{1)}$} & & Hourly depreciation cost of machines $i$ in the factory & $\mathrm{JPY} / \mathrm{hr}$ & $\sum\left(d_{i} / h\right)$ \\
\hline & $d_{i}$ & Yearly depreciation cost of machine $i$ & JPY/year & $M_{i}\left(1-s a l_{i}\right)\left(1+m m_{i}\right) / m d_{i}+s_{i} A V I_{i}$ \\
\hline & $M_{i}$ & Purchase price of machine $i$ & JPY & In Table 3 \\
\hline & $s a l_{i}$ & Salvage rate of machine $i$ & & In Table 3 \\
\hline & $m m_{i}$ & Maintenance rate of machine $\mathrm{i}$ & & In Table 3 \\
\hline & $m d_{i}$ & Depreciation years of machine $i$ & years & In Table 3 \\
\hline & $s_{i}$ & Rate of insurance, interest, and tax & & In Table 3 \\
\hline & $A V I_{i}$ & Average value of yearly interest & JPY/year & $M_{i}\left(1-\operatorname{sal}_{i}\right)\left(1+m d_{i}\right) / 2 m d_{i}+M_{i} s a l_{i}$ \\
\hline \multirow[t]{4}{*}{$Z$} & & Hourly variable cost in the factory & $\mathrm{JPY} / \mathrm{hr}$ & $l+($ ele + fuel $) / h$ \\
\hline & 1 & Hourly cost for five workers & $\mathrm{JPY} / \mathrm{hr}$ & 12,500 \\
\hline & ele & Annual cost of electricity & Mill. JPY/year & 6.8 \\
\hline & fuel & Annual cost of diesel fuel and oil & Mill. JPY/year & 3.9 \\
\hline
\end{tabular}

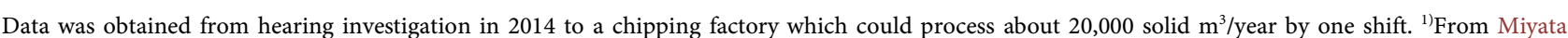
(1980). ${ }^{2}$ According to Japanese tax law. 
Table 3. Cost data of machines for chipping at the factory.

\begin{tabular}{cccccc}
\hline Machine & & $\begin{array}{c}\text { Fixed } \\
\text { chipper }\end{array}$ & $\begin{array}{c}\text { Grapple } \\
\text { loader }\end{array}$ & $\begin{array}{c}\text { Shovel } \\
\text { loader }\end{array}$ & $\begin{array}{c}\text { Wheel } \\
\text { loader }\end{array}$ \\
\hline Index & $i$ & 1 & 2 & 3 & 4 \\
Purchase price of machine $i$ (Mill. JPY) & $M_{i}$ & 27.1 & 9.7 & 1.0 & 8.9 \\
Salvage rate of machine $i$ & $s a l_{i}$ & 0.1 & 0.1 & 0.1 & 0.1 \\
Maintenance rate of machine $i$ & $m m_{i}$ & 0.5 & 0.5 & 0.5 & 0.5 \\
Depreciation years of machine $i$ & $m d_{i}$ & 8 & 8 & 8 & 8 \\
Rate of insurance, interest, and tax & $s_{i}$ & 0.23 & 0.23 & 0.23 & 0.23 \\
\hline
\end{tabular}

Data was obtained from hearing investigation in 2014 to a chipping factory which could process about 20,000 solid $\mathrm{m}^{3} /$ year by one shift.

There were two types of road standard which differed by the driving velocity. The driving velocity was $50 \mathrm{~km} / \mathrm{hr}$ on primary roads and $30 \mathrm{~km} / \mathrm{hr}$ on secondary roads, respectively. The gravity points of city municipalities represented the material landings, and the total number of material landings $J$ was 31 out of $33 \mathrm{mu}$ nicipalities because two of them were not extracted for the insufficient GIS data. The average distance was $86.7 \mathrm{~km}(\mathrm{SD}=29.3 \mathrm{~km}, \operatorname{Max}=135.3 \mathrm{~km}, \operatorname{Min}=19.3$ $\mathrm{km}$ ) between the demand and material landing $j$. Each landing had the amount of material $V_{p}$ which was calculated based on the thinning volume. Those processes were described in the previous study in detail (Yoshida \& Sakai, 2017), and the harvested volume was kept under the annual increment.

In the promoted system, trucks were assumed to have the payload of 10 tons and the capacity of 20 loose $\mathrm{m}^{3}$, which was the standard size for round wood and chip transportation from landings in the forest in Japan. The transportation at the full volume capacity was applied to the analysis which meant the material should not have more than $30 \%$ of moisture content on the wet basis (Yoshida, Son, \& Sakai, 2017).

In the conventional system, the transportation cost for round wood was set by the association according to the straight distance between the power plant and the material landing $j$ and it was converted to the chip volume as shown in Table 4. The straight distance was measured on GIS in this study.

\subsection{Allocation Strategy and Cost Simulation}

The entire supply cost to the demand $C_{s p}$ (JPY/loose $\mathrm{m}^{3}$ ) was calculated by the Equation (2) while satisfying the Equations (3) to (7).

$$
\begin{gathered}
C_{s p}=\sum_{i \in I}\left(C_{c h i p, i}+\sum_{j \in J} x_{i j} C_{t r, i j}\right) / D \\
\sum_{i, j \in I, J} x_{i j} \geq D \\
\sum_{i \in I} V_{i} \geq D \\
\sum_{i \in I} x_{i j} \leq V_{j} \\
\sum_{j \in J} x_{i j} \leq V_{i}
\end{gathered}
$$


Table 4. The agreed transportation cost of low-quality round wood converted to the unit of chip volume.

\begin{tabular}{cc}
\hline $\begin{array}{c}\text { Straight distance from the power } \\
\text { plant to the material landing } j(\mathrm{~km})\end{array}$ & Transportation cost $\left(\mathrm{JPY} /\right.$ loose $\left.\mathrm{m}^{3}\right)$ \\
\hline$<20$ & 857 \\
$<30$ & 964 \\
$<60$ & 1071 \\
Over 60 & 1339 \\
\hline
\end{tabular}

Data was obtained from hearing investigation to the association in 2013. The unit was converted from $\mathrm{JPY} /$ solid $\mathrm{m}^{3}$ to JPY/loose $\mathrm{m}^{3}$ by using the chip density coefficient of 2.8 loose $\mathrm{m}^{3} / \mathrm{solid}^{3}$ (Serup et al., 2002).

$$
x_{i j} \geq 0
$$

where $C_{c h i p, i}$ was the chipping cost of the supplier $i$ (JPY/loose $\mathrm{m}^{3}$ ); $x_{i j}$ the amount of chip transported by the supplier $i$ from the material landing $j$ in the promoted systems or the amount of round wood from the material landing $j$ in the conventional system (loose $\mathrm{m}^{3}$ ); $C_{t r, i p}$ the unit transportation cost of the wood chip by the supplier $i$ from the material landing $j$ in the promoted system or the unit transportation cost of round wood from the material landing $j$ in the conventional system (JPY/loose $\mathrm{m}^{3}$ ); $D$, the size of annual demand which was 378,000 loose $\mathrm{m}^{3}$ in this study (loose $\mathrm{m}^{3}$ ); $V_{p}$, the annual production volume by the supplier $i$, which should be satisfied for the depreciation of chipper (loose $\left.\mathrm{m}^{3}\right) ; V_{p}$ the annual amount of material at the material landing $j$ (loose $\mathrm{m}^{3}$ ); $I$, the total number of suppliers in a supply chain; and $J$ was the total number of landings which was 31 in this study. The amount of round wood in the conventional system was converted to the unit of chip volume by the chip density coefficient $e$ of 2.8 loose $\mathrm{m}^{3}$ /solid $\mathrm{m}^{3}$ (Serup et al., 2002).

In the constraint (3), it was described that the sum of the production volume from each material landing should satisfy the demand. In the constraints (4) and (5), the number of suppliers $i$ which was necessary to satisfy the demand while keeping the production for machine depreciation was defined. In the constraint (6), the production volume was restricted not to exceed the material volume at the landing $j$. The annual production volume by the supplier $i$ required for its depreciation $V_{i}$ was set when the rate of machine utilization was 0.75 (Yoshida \& Sakai, 2017). All of the values were summarized in Table 5.

The allocation strategy of mobile chippers expressed the priority of landing assignment to obtain the annual production volume $V_{i}$. The chipper which assigned to "closer" strategy is assigned to the material landings closer to the demand on the priority basis. The four cases for analysis was presented according to the combination of different sizes of mobile chippers. Those were called the cases S, M-S, S-M, and M, respectively (Table 6). Firstly, the supply chain using only small chippers was supposed in the case S. Secondly, the combinational use of small and middle chippers was supposed in the cases M-S and S-M. The case 
Table 5. Values for cost calculation.

\begin{tabular}{|c|c|c|c|c|c|}
\hline \multirow{2}{*}{ Symbol } & & \multirow{2}{*}{ Definition } & \multirow{2}{*}{ Unit } & \multicolumn{2}{|c|}{ Data and equation } \\
\hline & & & & Promoted & Conventional \\
\hline$C_{c h i p, i}$ & & $\begin{array}{l}\text { Chipping cost } \\
\text { of the supplier } i\end{array}$ & $\mathrm{JPY} /$ loose $\mathrm{m}^{3}$ & Table 1 & Equation (1) \\
\hline$x_{i j}$ & & $\begin{array}{l}\text { The amount of wood chip } \\
\text { produced by the chipper } i \text { or } \\
\text { round wood transported from } \\
\text { the material landing } j\end{array}$ & loose $\mathrm{m}^{3}$ & \multicolumn{2}{|c|}{ Variable } \\
\hline$C_{t t, i j}^{1)}$ & & $\begin{array}{l}\text { Transportation cost } \\
\text { of the supplier } i \text { from the } \\
\text { landing } j \text { to the demand or } \\
\text { the unit transportation } \\
\text { cost of round wood from } \\
\text { the material landing } j \text { in the } \\
\text { conventional system }\end{array}$ & JPY/loose $\mathrm{m}^{3}$ & GIS database & Table 4 \\
\hline$D$ & & Annual demand & loose $\mathrm{m}^{3}$ & \multicolumn{2}{|c|}{378,000} \\
\hline$V_{i}$ & & $\begin{array}{l}\text { Annual production volume } \\
\text { by the chipper } i \text { required } \\
\text { for its depreciation }\end{array}$ & loose $\mathrm{m}^{3}$ & $\begin{array}{c}\text { Small: } 9857 e \\
\text { Middle: } 35,534 e\end{array}$ & - \\
\hline$V_{j}$ & & $\begin{array}{l}\text { Annual amount of material } \\
\text { at the material landing } j\end{array}$ & loose $\mathrm{m}^{3}$ & $e z\left(u_{1}+u_{2}\right) V_{t i}$ & $e z u_{1} V_{t i}$ \\
\hline & $e^{2)}$ & Chip density coefficient & $\begin{array}{l}\text { loose } \mathrm{m}^{3} / \\
\text { solid } \mathrm{m}^{3}\end{array}$ & \multicolumn{2}{|c|}{2.8} \\
\hline & $z^{1)}$ & $\begin{array}{l}\text { Annual production rate by } \\
\text { thinning in the model area }\end{array}$ & & \multicolumn{2}{|c|}{0.0067} \\
\hline & $u_{1}^{1)}$ & $\begin{array}{l}\text { Rate of treetop volume to } \\
\text { stem volume without branches }\end{array}$ & & \multicolumn{2}{|c|}{0.4} \\
\hline & $u_{2}^{1)}$ & $\begin{array}{l}\text { Rate of branches } \\
\text { to stem volume }\end{array}$ & & 0.23 & - \\
\hline & $V_{t, j}$ & $\begin{array}{l}\text { Stock volume } \\
\text { in the municipality } j\end{array}$ & solid $\mathrm{m}^{3}$ & \multicolumn{2}{|c|}{ GIS database } \\
\hline
\end{tabular}

${ }^{1)}$ These were described in the previous study (Yoshida \& Sakai, 2017). ${ }^{2)}$ From Serup et al., (2002).

Table 6. Allocation strategy according to the combinationof mobile chippers.

\begin{tabular}{cc}
\hline Case & Allocation strategy \\
\hline $\mathrm{S}$ & Only using small chippers. \\
$\mathrm{M}-\mathrm{S}$ & Using both small and middle chippers. \\
$\mathrm{S}-\mathrm{M}$ & Allocate the middle chipper to the material landing closer to the demand. \\
$\mathrm{M}$ & Using both small and middle chippers.
\end{tabular}

M-S assigned the middle chippers to the closer material landings and the case $S-M$ was vice-versa. The number of middle chippers was set to one in the cases M-S and S-M to make this analysis simple. Finally, the supply chain using only 
middle chippers was considered in the case $\mathrm{M}$.

In the cases M-S and S-M, there were two-steps when solving the Equation (2). On the assumption that the supplier 1 owned the middle chipper, the Equation (2) is solved when the total number of suppliers $I$ is $\{1\}$ at first in the case M-S. In the case S-M, it is solved when the total number of suppliers $I$ is all suppliers except the supplier 1. Lp-solve package in R-language was used to solve the Equation (2). In addition to the supply costs, the average transportation distances from material landings to the demand were extracted by using GIS.

\section{Result}

The chipping cost at the factory was $1007 \mathrm{JPY} /$ loose $\mathrm{m}^{3}$ in the conventional system. Mobile chippers were more cost-effective than the chipping by a fixed chipper in the factory. The entire supply cost is summarized in Table 7 . The case $S$ needed 11 suppliers. In the cases M-S and S-M, one supplier used a middle chipper and eight suppliers used small chippers. Totally nine suppliers were necessary. In the case $M$, there were only four suppliers because of the higher productivity of middle chipper.

The selection of mobile chippers and the allocation strategy affected the entire supply cost. The cases S-M and M in the promoted system were more cost-effective than the conventional system. The supply cost of the case M-S was more expensive than that of the case S-M despite the same selection of chippers and the same number of suppliers. The standard deviation was varied in a wider range in the cases $S$ and M-S than the other cases.

About the cases M-S and S-M, the detail of the supply cost of each supplier is shown in Table 8. The supplier 1 using the middle chipper realized the minimum cost of its own in the case M-S. On the contrary, the supplier 1 supplied at a low cost from the farthest material landings and it contributed to reducing the average supply cost in the case S-M.

The transportation distance is summarized in Table 9. The transportation distance in the conventional system was longer than those of promoted systems since the conventional system used only low-quality round wood. It was also apparent that the allocation strategy influenced the transportation distance. The

Table 7. Results of cost calculation.

\begin{tabular}{cccccc}
\hline System & Conventional & \multicolumn{5}{c}{ Promoted } \\
\hline Case & - & S & M-S & S-M & M \\
\hline $\begin{array}{c}\text { Number of chip suppliers } \\
\text { within the supply chain }(I)\end{array}$ & - & 11 & 9 & 9 & 4 \\
Average of supply cost (JPY/loose $\mathrm{m}^{3}$ ) & 2,138 & 2377 & 2395 & 1885 & 1497 \\
SD (JPY/loose $\mathrm{m}^{3}$ ) & 159 & 710 & 804 & 236 & 251 \\
Maximum (JPY/loose $\left.\mathrm{m}^{3}\right)$ & 2347 & 3447 & 3447 & 2222 & 1760 \\
Minimum (JPY/loose $\left.\mathrm{m}^{3}\right)$ & 1865 & 1606 & 970 & 1536 & 970 \\
\hline
\end{tabular}


Table 8. The detail of supply costs in the cases M-S and S-M (JPY/loose $\mathrm{m}^{3}$ ).

\begin{tabular}{ccccccccccc}
\hline & \multicolumn{3}{c}{ CaseM-S } & & \multicolumn{5}{c}{ Case S-M } \\
\hline $\begin{array}{c}\text { Allocation } \\
\text { Strategy }\end{array}$ & $i$ & Chipper & Average & Max & Min & $i$ & Chipper & Average & Max & Min \\
\hline Closer & 1 & Middle & 1144 & 1317 & 970 & 2 & Small & 1606 & 1606 & 1606 \\
& 2 & Small & 1936 & 1936 & 1936 & 3 & Small & 1606 & 1606 & 1606 \\
& 3 & Small & 1940 & 1944 & 1936 & 4 & Small & 1771 & 1936 & 1606 \\
& 4 & Small & 2070 & 2195 & 1944 & 5 & Small & 1936 & 1936 & 1936 \\
& 5 & Small & 2209 & 2222 & 2195 & 6 & Small & 1940 & 1944 & 1936 \\
& 6 & Small & 2222 & 2222 & 2222 & 7 & Small & 2070 & 2195 & 1944 \\
& 7 & Small & 3035 & 3443 & 2222 & 8 & Small & 2209 & 2222 & 2195 \\
& 8 & Small & 3443 & 3443 & 3443 & 9 & Small & 2222 & 2222 & 2222 \\
Farthest & 9 & Small & 3445 & 3447 & 3443 & 1 & Middle & 1702 & 1760 & 1537 \\
\hline
\end{tabular}

Table 9. Summary of transportation distance by the sizes of chippers (km).

\begin{tabular}{cccccccc}
\hline System & Conventional & \multicolumn{7}{c}{ Promoted } \\
\hline Case & - & S & \multicolumn{2}{c}{ M-S } & \multicolumn{2}{c}{ S-M } & M \\
\hline Chipper size & - & Small & Small & Middle & Small & Middle & Middle \\
\hline Average & 64.2 & 49.8 & 54.2 & 32.3 & 42.8 & 61.3 & 49.8 \\
SD & 33.2 & 16.5 & 11.0 & 13.5 & 14.7 & 6.9 & 16.5 \\
Maximum & 116.8 & 71.8 & 71.8 & 46.2 & 60.9 & 71.8 & 71.8 \\
Minimum & 19.3 & 19.3 & 34.4 & 19.3 & 19.3 & 52.5 & 19.3 \\
\hline
\end{tabular}

average transportation distance of the suppliers using small chippers was longer in the case M-S than those in the case S-M, and vice versa in the case of the supplier using a middle chipper.

\section{Discussion}

The results of cases M-S and S-M clarified that the less productive chippers should be allocated to the material landings closer to the demand. The transportation was less efficient when using the less productive chippers because of the longer loading time that was as same as the chipping time (Yoshida \& Sakai, 2017). This longer loading time reduces the driving time of a truck and it can lead to the increase of the number of trucks in the shuttle system if the transportation distance becomes long. It was essential for the less productive chippers to keep shorter the transportation distance as much as possible in a supply chain with multiple suppliers for the better productivity of the entire supply chain.

The standard deviation expressed the variance in the supply cost among suppliers in the supply chain. The cases with less variance in the average supply cost such as the cases S-M and $\mathrm{M}$ were more robust to the change of wood chip price. Therefore, the cases S-M and M were also recommended to stabilize the supply 
with the entire supply cost reduced.

The great and concentrated demand inevitably makes transportation distance longer and must collaborate with the suppliers to reduce the chip supply cost. The demand can support suppliers by some means, such as preparing material at closer landings or renting middle chippers to small suppliers to realize the case $\mathrm{M}$ as a best practice. It is necessary to foster the development of a partnership between the suppliers and the demand.

While this study dealt with a tactical problem in wood chip supply chain management by solving a simple linear programming model, optimization by linear and mixed integer programming models has also been used to solve practical problems on operational level considering the cost of relocation and drying in harvesting and transportation (e.g. Acuna, Anttila, Sikanen, Prinz, \& Asikainen, 2012; Ghaffariyan et al., 2017; Han, Chung, Wells, \& Anderson, 2018; Zamora-Cristales, Sessions, Boston, \& Murphy, 2015). It was also pointed out that the best solution to realize the least cost of the entire supply chain would cause the conflict among stakeholders due to the contract provisions such as the unit of payment (Han et al., 2018) as similar to the situation of the supplier 1 in cases $\mathrm{M}-\mathrm{S}$ and S-M of this study. By providing the optimized solution, the possible conflict in the supply chain was specified and stakeholders would be able to resolve it (Han et al., 2018).

From the aspect of the supplier 1 who had the middle chipper in the cases M-S and S-M, the supplier 1 would prefer the case M-S because of the better economy of its own. To realize the case S-M, it would be essential to solve this conflict by sharing the benefits brought by the collaboration based on transparent information (Simatupang \& Sridharan, 2005) which enabled to ensure the collaboration among stakeholders (Lehoux, D'Amours, \& Langevin, 2014) and to sustain the supply chain (Rijal \& Lussier, 2017). The result of this study corroborates these previous researches about stakeholder collaboration and its benefit.

In conclusion, this study shows both optimal and non-optimal solution by simulating the combination of different mobile chippers. It was found that the less productive chippers should be allocated closer to the demand to obtain the optimal solution when several chippers with different productivity owned by suppliers. Such allocation strategies and management will improve the stability of the supply chain with the entire supply cost reduced. The possible conflict was specified as the increased cost of the suppliers using more productive chippers. To realize and sustain better management, it is essential to resolve such conflict by making a collaborative relationship among stakeholders.

\section{Acknowledgements}

This work was supported by JSPS KAKENHI Grant Number JP256455.

\section{Conflicts of Interest}

The author declares no conflicts of interest regarding the publication of this paper. 


\section{References}

Acuna, M., Anttila, P., Sikanen, L., Prinz, R., \& Asikainen, A. (2012). Predicting and Controlling Moisture Content to Optimise Forest Biomass Logistics. Croatian Journal of Forest Engineering, 33, 225-238.

D’Amours, S., Rönnqvist, M., \& Weintraub, A. (2009). Using Operational Research for Supply Chain Planning in the Forest Products Industry. INFOR: Information Systems and Operational Research, 46, 265-281. https://doi.org/10.3138/infor.46.4.265

Ghaffariyan, M. R., Brown, M., Acuna, M., Sessions, J., Gallagher, T., Kühmaier, M., Egnell, G. et al. (2017). An International Review of the Most Productive and Cost Effective Forest Biomass Recovery Technologies and Supply Chains. Renewable and Sustainable Energy Reviews, 74, 145-158. https://doi.org/10.1016/j.rser.2017.02.014

Ghaffariyan, M. R., Sessions, J., \& Brown, M. (2013). Roadside Chipping in a First Thinning Operation for Radiata Pine in South Australia. Croatian Journal of Forest Engineering, 34, 91-101.

Han, H., Chung, W., Wells, L., \& Anderson, N. (2018). Optimizing Biomass Feedstock Logistics for Forest Residue Processing and Transportation on a Tree-Shaped Road Network. Forests, 9, 121. https://doi.org/10.3390/f9030121

Intergovernmental Panel on Climate Change (2014). Climate Change 2014: Synthesis Report, Contribution of Working Groups I, II and III to the Fifth Assessment Report of the Intergovernmental Panel on Climate Change [Core Writing Team, R.K. Pachauri and L.A. Meyer (Eds.)]. Genova: IPCC. https://doi.org/10.1017/CBO9781107415416

Japanese Forestry Agency (2018). Annual Report on Forest and Forestry in Japan, Fiscal Year 2017. Tokyo.

Kuboyama, H., Komata, H., \& Yanagida, T. (2017). Conditions for Establishing a Combined Heat and Power Station by Using Unutilized Wood Biomass. Journal of Japanese Forestry Society, 99, 226-232. https://doi.org/10.4005/jjfs.99.226

Kumar, A., Cameron, J. B., \& Flynn, P. C. (2003). Biomass Power Cost and Optimum Plant Size in Western Canada. Biomass and Bioenergy, 24, 445-464.

https://doi.org/10.1016/S0961-9534(02)00149-6

Laitila, J., Asikainen, A., \& Ranta, T. (2016). Cost Analysis of Transporting Forest Chips and Forest Industry By-Products with Large Truck-Trailers in Finland. Biomass and Bioenergy, 90, 252-261. https://doi.org/10.1016/j.biombioe.2016.04.011

Lehoux, N., D’Amours, S., \& Langevin, A. (2014). Inter-Firm Collaborations and Supply Chain Coordination: Review of Key Elements and Case Study. Production Planning \& Control, 25, 858-872. https://doi.org/10.1080/09537287.2013.771413

Marchi, E., Chung, W., Visser, R., Abbas, D., Nordfjell, T., Mederski, P. S., Laschi, A. et al. (2018). Science of the Total Environment Sustainable Forest Operations (SFO): A New Paradigm in a Changing World and Climate. Science of the Total Environment, 634, 1385-1397. https://doi.org/10.1016/j.scitotenv.2018.04.084

Miyata, E. S. (1980). Determining Fixed and Operating Costs of Logging Equipment. Washington DC: U.S. Department of Agriculture Forest Service.

Rijal, B., \& Lussier, J. M. (2017). Improving Sustainability of Value-Added Forest Supply Chain through Coordinated Production Planning Policy between Forests and Mills. Forest Policy and Economics, 83, 45-57. https://doi.org/10.1016/j.forpol.2017.06.003

Serup, H., Falster, H., Gamborg, C., Gundersen, P., Hansen, L., Heding, N., Thomsen, I. M. et al. (2002). Wood for Energy Production. Technology-Environment-Economy (2nd Revised ed.). Denmark.

Simatupang, T. M., \& Sridharan, R. (2005). An Integrative Framework for Supply Chain 
Collaboration. The International Journal of Logistics Management, 16, 257-274. https://doi.org/10.1108/09574090510634548

Simchi-Levi, D., Kaminsky, P., \& Simchi-Levi, E. (2008). Designing and Managing the Supply Chain; Concepts, Strategies and Case Studies. (3rd ed.). New York: McGrawHill/Irwin.

Wolfsmayr, U. J., \& Rauch, P. (2014). The Primary Forest Fuel Supply Chain: A Literature Review. Biomass and Bioenergy, 60, 203-221. https://doi.org/10.1016/j.biombioe.2013.10.025

Yoshida, M., \& Sakai, H. (2014). Fuel Chip Supply System with Low Price Mobile Chippers. Croatian Journal of Forest Engineering, 35, 9-14.

Yoshida, M., \& Sakai, H. (2017). Selection of Chipper Engine Size Based on Business Scale and Optimised Cost of Chipping and Transportation. Journal of Forest Research, 22, 265-273. https://doi.org/10.1080/13416979.2017.1368168

Yoshida, M., Berg, S., Sakurai, R., \& Sakai, H. (2016). Evaluation of Chipping Productivity with Five Different Mobile Chippers at Different Forest Sites by a Stochastic Model. Croatian Journal of Forest Engineering, 37, 309-318.

Yoshida, M., Fujiwara, M., \& Sakai, H. (2015). A Proposal of a Site Preparation System Combined with Chipping Operation. In International Conference: Reforestation Challenges (pp. 211-216). Belgrade: REFORESTA.

Yoshida, M., Son, J., \& Sakai, H. (2017). Biomass Transportation Costs by Activating Upgraded Forest Roads. Bulletin of the Transilvania University of Brasov, Special Issue Series II: Forestry, Wood Industry, Agricultural Food Engineering, 10, 81-88.

Zamora-Cristales, R., Sessions, J., Boston, K., \& Murphy, G. (2015). Economic Optimization of Forest Biomass Processing and Transport in the Pacific Northwest USA. Forest Science, 61, 220-234. https://doi.org/10.5849/forsci.13-158 